\author{
Aladeloba E.O., Olawale S.B., *Okesoto, J.0., Mnitp, RTP., Alabi, J.0, Ajibi, I.J, Adesiyan, O.R \\ banjiokesoto@gmail.com
}

Abstract: The paper espouses the historical origin of the Oluwole phenomenon in Lagos Nigeria. The study is a combination of desktop and surveying research. The desktop approach reviews existing literature on the historical evolution of Oluwole phenomenon in Lagos, Nigeria. The survey approach involves researchers as participants' observer, soliciting for some landed documents and exchange of foreign currencies. Results obtained were literary expressed and inferences made on them. Data solicited include the mode of operation of Oluwole phenomenon actors, the operators, and their demographic, ethnographic and socio-economic characteristics. The study reveals that Oluwole phenomenon as spatial and contextual challenges resulted from dysfunctional governance exhibited in the nation's political instability, ineffective physical planning and social segregation within the built environment. The paper recommends for inter-governmental agency relationship and co-operation, promotion of participatory governance, planning of socially inclusive cities among others, as a way of preventing social environmental menace like the Oluwole phenomenon.

Keywords: Built environment, environmental menace, governance, good governance and Oluwole phenomenon.

\title{
INTRODUCTION
}

One of the most dangerous, deadliest, but unnoticeable environmental issues of the Nigerian polity and the social environmental issue is the Oluwole enigma (Bajulaye, 2004). The Oluwole phenomenon over the years has reduced the nation's integrity among committee of nations in and outside the shores of African continent to a distorted and dwarfed political and social giant. Commentators on several occasions at different forums have described the nation as a country of 419ers and in the opinion of the former prime minister of Britain Micron Cameroun who described Nigeria as being fantastically corrupt. The phenomenon of Oluwole in the context of this paper is considered as an environmental issue that has reduced our social, economic and political sensibility as a nation. In 1999, the esteemed office of the lower chamber of the Nation's national assembly - the house of representative capitulated into the hands of the Oluwole phenomenon. The speaker of the house of Representative, Salisu Buhari faced charges of, age falsification and forgery of University certificate. As such, he was impeached on this ground in a sensational story tagged - "the Buhari gate". Bajulaye once describes Oluwole as Nigeris's hot spot where anything could be bought.

Oluwole phenomenon pre-dates 1999 , but its prevalence and spread to the other parts of the country and human lives made further research on the phenomenon a worthy one, despite government's efforts. Oluwole phenomenon is synonymous with forgery and counterfeiting of all manner of documents, ranging from government official documents, seals, government officials signatures to private commercial and economic falsifications. Oluwole is a place of dirty economic transactions where exists, overlaps, exchanges, alliances and various forms of consortia and interaction involving the legal, semi-illegal and illegal activities that take place in an urban environmental context. Olawale (2013) observes that Oluwole phenomenon is the intrigue between the real and abstract, official and unofficial, local and international, legal and illegal identity, morality and immorality.

The paper assumes that Oluwole phenomenon is an environmental maladies which originated, grew and sustained by failure in governance. A manifestation of failure of governments', economic, physical and political 
policies as a nation called the giant of Africa. It is an embodiment of Nigerian factor - corruption, a paradox of the state. Oluwole phenomenon in the description of Joseph, (1987) is an official and unofficial instrumentality of wealth creation, the complex channel of encountering, accessing, misappropriating, and interaction between the dysfunctional Nigerian state and the agency and the negative use of artistry of its citizenry. In the opinion of Bass et al , 2005) governance is the exercise of authority, the decisions, regulations and enforcement of how we will act and who will benefit. Good governance translates into fair and transparent management of societal resources to the maximum benefits of all. However in this part of the country, the citizens take into social deviance as a reaction to the perceived inequality between them (the poor) and the few rich members of the society who enjoy the greater proportion of the society's resources while many of the poor bears the incidence of the inequality resulting from poor governance., As observes by Waldman (2005) governance failure lies largely behind the many social maladies of most developing countries of the world. The paper therefore assumes that good governance is crucial to development, reduction of social defiance and crime and poverty alleviation.

The paper therefore aims at assessing the events that sustain Oluwole phenomenon with the view of reducing this phenomenon through sustainable good governance and political diplomacy.

\section{Related Researches}

OLuwole phenomenon has attracted little or no academic research expedition, but has largely attracted sensational reports from newspaper journalists at both local and international fronts, which in most cases does not go beyond sensationalism. Such attention has observes by Davies et. al, (1999) has not gone beyond exposition of crime and not as an environmental menace. However, several of those publications have thrown the sustainability of such phenomenon at the door step of poor governance, resulting from porosity of the state's security network and failure of the state in meeting with its social responsibilities to its citizens. In the academic fronts, little attention has been given and in most cases not in the realm of environmental expertise like the physical planner and other environmentalists. Though social thinkers like the sociologists consider the phenomenon as clear examples of sustained deviant behavior or a criminal activity sustained by the environment.

For example Olawale, (2010) sees Oluwole phenomenon as a metaphor through which concepts, beliefs and relationship that explain the means and exercise of power by the state are formed, reviewed, challenged and recomposed. In the opinion of Bayant et. al. (1999) Oluwole phenomenon is not an isolated phenomenon but an integral part of a larger phenomenon, which its members use to question legitimacy, representation, and regulatory power of its government. This paper equally submits to this assumption, though from the social view of a physical planner.

Joseph, (1987) opines that Oluwole phenomenon is a product of the systematic decay and dysfunctionality of the Nigerian state. Suggesting, that Oluwole phenomenon is a revolt or disengagement strategy by the citizenry to the nation - Nigeria in the face of socio-economic decline and state's institutional and machinery of governance collapse. A hypothesis supported by this paper.

Clapham, (1994) equally submits that Oluwole phenomenon is a reflection of governance failure. It is an informed set of attitude against the state, government and politics prevalent in Nigeria. As such, constitute an attitude similar to using the paraphernalia of the state and officialdom (documents, signatures, marks, positions, stamps, and seals) and means to an end.

The consensus opinion is that Oluwole phenomenon is a consequence of a failed state. This paper contributes to the previous studies by giving the historical origin of the Oluwole phenomenon and how out of this historical foundation, element of governance failure in areas of political and physical planning have significantly contributed to the rising and sustainability of this challenge. In addition rather than seeing the phenomenon in the realm of criminology, the paper espouses the environmental aspects of Oluwole phenomenon. 


\section{The Study Area}

Oluwole is an old part of the Lagos Central Business District (CBD) comprises of about six streets, a host to a local and well fortified police station. Oluwole is a stone thrown distance to the Lagos (Nigeria) Stock Exchange building and very close to the former headquarters of Central Bank of Nigeria and closely surrounded by several banking and insurance offices and major retail outlets. The settlement is named after a $19^{\text {th }}$ century king of Lagos Oba Oluwole (1836 - 1841), (Fashina and Folami, 1982). Oral history reported that the king died mysteriously and his retinues of palace servants called Ilaris were re-settled in the area now known as Oluwole Deistrict. The area exists at the edge of the old traditional Lagos - IsaleEko, measuring about 13 square kilometers with about 30,000 in habitants in 1859 as documented by Baker, (1974). Other inhabitants apart from the palace servants include; the resettled freed slaves from Sierra Leone (Saros), Brazil and Portugal (Anans) in 1861 and the Egba refugees in 1867. The area latter became the heart of the old Lagos surrounded in the North by the traditional Isale - Eko quarters, in the South West by the Olowogbowo quarters where the Saros are found, towards the east is the Aguda quarters where Anans are found and along the South East is the European quarters which now constitute the present day, Onikan, Ikoyi, Marina and Victoria Island, (Baker, 1974 and Peil, 1991).

\section{Research Method}

Research method was both desktop and survey. The desktop approach involves the review of similar works and historical works on Lagos. The survey method was field base. The field base method was quite challenging and interesting because of the sensitive nature of the investigation. Method adopted was primarily researchersparticipants observer. The researcher introduced self as client interested in obtaining land document to facilitate visa requirement for travelling to Canada and exchange of United State of America dollars. Vigilance was the watchword, funds were parted with and daily memory of the operations were temporarily stored and immediately reproduced for documentation and analysis. Observations include; mode of operation, ethnography, demographic and socio-economic characteristics of the operators. The investigation lasted few weeks and in the end, counterfeited certificate of occupancy was produced and fake dollars were obtained.

\section{FINDINGS}

The research findings are discussed in two parts, the first part is qualitative, and this espouses findings made from literature gathering. This part discusses the historical evolution of the Oluwole phenomenon. The second part is a derivative of the field survey. It discusses the mode of operation, operational context and the characteristics of the operators.

\section{Historical Evolution of Oluwole Phenomenon}

The works of Heap, (2000), Davies (1999), Baker,(1974), Ismail,(2010), Joseph, (1987) and Claphan, (1994) were reviewed for this purpose. Deductions from these works show that Oluwole phenomenon began with deception which started with the Boma "Boys"1 who seized opportunity of their positions to dupe school boys of their money on the pretext of promise of jobs on board (ships). The school boys after parting with their school fees soon discovered they had been duped and deceived became afraid to go home and face punishment from their parents. They began to loiter about and gradually grow to become Boma Boys themselves.

To these authors; poverty, unemployment, breakdown of traditional family system and lack of parental control and stable home gave rise to the growth of the Boma Boys' phenomenon in the early 1920s in the Oluwole area of Lagos. The Boma boys syndrome later metamorphosised into Jaguda boys ${ }^{2}$ in the late 1920 s, later re-enacted into Boma boys in the 1940s and thugs and touts in the 1950s and in the recent area boys or and the Oluwole boys.

1. Boma Boys were products of unlicensed guides for Sailors, Pimp agents, beggars, petty thieves and destitute. 
2. Jaguda Boys are historical predecessors of contemporary area boys essentially pick packets and petty thieves.

\section{The Rise of Oluwole Phenomenon: The Role of History and Governance}

The preparation of Nigeria for independence and the designation of Lagos as the capital led to the proposition of the Central Lagos slum clearance Scheme (CLSCS) in 1951. The scheme was designed to prepare the old Lagos of its new capital status by getting rid of slums and redevelopment. The seventy acre triangular Oluwole was selected because of its proximity to key government institutions. This will directly affect the house of about 30,000 inhabitants. The Lagos Executive Development Board which was established in 1928 was tasked with the responsibility of executing this scheme however, the scheme failed for a large number of reasons, some of which include;

i. Poor planning which did not envisaged the majority of problems associated with the scheme for example the uprising against the scheme and the huge momentary demand for compensation requirement.

ii. Political instability which resulted from political friction between Lagos city council and the Kofo Abayomi led LEDB owing to their ambiguous and overlapping roles in Town Planning and Urban Development. In certain instances, the LEDB on the basis of enabling the Town and Country Planning Act of 1932, 1946 and 1958 made decision regarding zoning, demolition, re-housing, redistribution, payment of compensation and compulsory acquisition. The Lagos city council kept on granting approval for building plans even on publicly acquired lands. This friction led to disagreement, delays, inaction, loss of property and income.

iii. Politicization of the scheme. The Lagos city council was elected and accountable to Lagosians, as such subjected to the pressures from the electorates, while the LEDB was an appointed body controlled by the Central government through the ministry of Lagos affairs. The LCC on the other hand was busy protecting the interests of its supporters who are sympathetic to Action Group (AG). The LEDB was arrogantly protecting the national interest only as defined by Northern People's Congress (NPC). The implementation of the scheme became a channel for siphoning the economic fortunes of the country and as a medium of for rewarding political patronage at the expense of the actual implementation of the scheme.

\section{Inferences}

Historically, Oluwole is a segmented abandoned area of Lagos, originally made up of the outcasts - the slaves (Ilaris), the Egba refugees and the freed slaves. Their heterogeneous demographic and ethnographic characteristics promote loss of social values and morale, a motivating agent for prevalence of crime as evidenced by Davies et.al, (1999)

The failure of governance in the execution of the proposed redevelopment scheme equally perpetuates and gave birth to the Oluwole phenomenon. The failure on government part made Oluwole district to develop into a mixture of redeveloped and undeveloped plots. With some vacated but not demolished houses, surrounded by retails shops, banks and government agencies offices, such houses became abandoned houses and popularly referred to as "free houses" and became hide outs for the idle members of the society who in turn develops and perpetuate their mastery art for nefarious activities. It can therefore be inferred that the poorly planned displacement of the traditional owners (though of heterogeneous background) of Oluwole land that break the social cohesion in the district and brought about the birth of Oluwole phenomenon.

\section{Operational Mode}

Operational modes in Oluwole regarding Oluwole phenomenon is swift, well organized and skillful and capable of beating any nation security network. The operation is characterized by three hierarchies namely: 


\section{The Olus}

This is the highest hierarchy mostly made up of the entrepreneurs i.e. the owners of the business. They are the most senior actors who have personal shops. This group regulates and oversees security at Oluwole. By virtue of telephone conversations they make, it could be inferred that they are well connected to the security agents. All of them speak good English and more of the local citizens i.e. the Yorubas. Though, they exist alongside other minority groups; the Edos and Deltas and few Igbos. Mostly dominated by the male gender.

\section{The Draughtsman and the Draughtswoman}

This group are the main working instruments, comprises of men and women who are skillful sign writers. They are five and copy artists. They work perfectly on the computer, capable of counterfeiting any signature, symbols, seals etc. They are regularly called Irinse (instrument). They are the nucleus of Oluwole business.

\section{The Street Vendors}

This is the least hierarchy in the operational modes of Oluwole business. They stand ordinarily on the street soliciting for potential customers. They are the foot soldiers who keep watch on security operatives and alarm the Olus anytime they sense unusual security movements.

\section{The Operators}

The operators ranging from the Olus to the street vendors are generally of the two sexes - the Olus are more dominated by the male sex, though no empirical measurement was made.

The draughtsman and the draughtswomen are like the Olus having equal sex proportion and the street vendors have more men than women.

\section{Deliverables}

Operation in Oluwole is capable of delivering wide range of dirty economic tricks, services and deception. Their deliverable could best be discussed as game of chance and done by the reason of quest for money and wealth. Not necessarily a protest against the dysfunctional system.

They specialize in more of document crimes who Davies,(1999) describes as invisible crime. Some of their deliverables include; but not limited to; falsification of official accords, internet business scams, marketing and production of travel documents such as identity changing of international passports called "Ori-olori; vehicle license, local purchasing orders (LPO.s) Certificate of occupancy.Government letter head papers, official signatures of; government officials, philanthropists, Bank MDs, court orders, identify cards, visas, arrest warrants among others.

\section{CONCLUSION AND RECOMMENDATIONS}

Oluwole phenomenon evolves over space and time as a result of failure of governance. In Lagostodaythe poor in reminiscence of the Oluwole phenomenon spatial expression are been segregated in term of where they live. The poor are been pushed to the outskirts of the city far away from their places of economic and employment opportunities and area devoid of social amenities and public services. The poor are drifting to the suburbs and far away from areas in around the city centers because of their inability to afford housing costs in these areas. It is a matter of time, the exclusionary hosing system of the state will crescendo into total segregation which may give rise again to another Oluwole- like phenomenon. To prevent this, the paper recommends for good governance achievable through; participatory and transparent governance. Inclusionary city planning, intergovernmental agency cooperation and clear definitions of their duties. Stability and continuity of government activities, the need to separate partisan politics from government and public policies. Promotion of civil liberties and provision of social security services will all help stem down the growth of the Oluwole phenomenon in the society. 


\section{REFERENCES}

1. Baker P. (1974). Urbanization and Political Change; Politics of Lagos, 1917 - 1967. London; University of California Press.

2. Bajulaye, O. (2004). Nigeria: Oluwole: Where anything could e bought in Daily Trust of May 20, 2014.

3. Bass, S., Reid, H., Satterthwaite, D. and Steele, P. (2005). Reducing poverty and sustaining the environment: The politics of local engagement. Earthscan, London.

4. Boryat J.F. Ellis S. and Hibou, B. (1999). The Criminalization of the States in Africa, London, James Carrey Publishing.

5. Clapham, C. (1994). The longusDurect of the African States. African Affairs. Vol. 93 NO. 372. Pp 433 - 439.

6. Fasinro, HAB (2004). Political and Cultural Perspectives of Lagos. Lagos, Academy Press.

7. Folami, T. (1982). History of Lagos, Nigeria New York; Exposition Press.

8. Fourchard L. (2003). "Security, Crime, and Segregation in Historical Perspectives in Nigeria; 1920 - 1960. Journal of Africa History Vol. 47 pp 115 - 137.

9. Heap, S. (2000). "Colonial Area Boys: Male Juvenile Delinquents on Lagos Island; Paper presented at Conference on Africa; Past, Present and Future. African studies Association of the UK Biennial Conference September 11 - 13, Trinity College, Cambridge.

10. Joseph, R. (1987). Democracy and Partisan Politics in Nigeria: The Rise and Fall of Second Republic Cambridge; Cambridge University Press.

11. Olawale, Ismail (2010). Deconstructing "Oluwole" Political Economy at the Margins of the State. In Adebunmi, A. and Obadare, E. Encountering (eds) of the Nigerian State, Palmgrove Macmillan Publishing Ltd.

12. Reil, M.C. (1991). Lagos: The City and Its People. London: Belhaven Press.

13. Davies, P. Francis, P. and Jupp. V. (1999). “The features of invisible crime” London; Macmillan PP. 3 - 28.

14. Waldman, L. (2005). Environment, politics and poverty: Lessons from a review of PRSP skakeholder perspectives. Institute of Development Studies, Brighton.

Citation: Aladeloba E. O., Olawale S.B., Okesoto, J.O., Mnitp, RTP., et. al. "The Making of Oluwole: An Aftermath of Governance Failure in Nigeria". American Research Journal of Humanities and Social Sciences, vol 5, no. 1, 2019 , pp. 1-6.

Copyright (C) 2019 Aladeloba E. O., Olawale S.B., Okesoto, J.O., Mnitp, RTP., et. al, This is an open access article distributed under the Creative Commons Attribution License, which permits unrestricted use, distribution, and reproduction in any medium, provided the original work is properly cited. 